\title{
Interstitial deletion of chromosome 7q in a patient with Williams syndrome and infantile spasms
}

Received: April 27, 1998 / Accepted: May 29, 1998

\begin{abstract}
Interstitial deletion of 7q11.23-q21.11 was identified by cytogenetic methods in a 4-year-old boy with Williams syndrome (WS) and infantile spasms. Deletion of the elastin $(E L N)$ gene and the DNA polymorphic markers, D7S1870, D7S2490, D7S2518, and D7S2421, were identified in the patient, but the loci for D7S653 and D7S675 were not involved. Zackowski et al. (1990) reported that 6 of 16 patients with the interstitial deletion of 7q11.2-q22 had abnormal electro encephalograms, or seizures, or both, and that infantile spasms were present in 2 of the 6 patients. WS is a well defined developmental disorder characterized by distinct facial features, gregarious personality, and congenital heart defects. Seizures are not generally associated with this syndrome. WS commonly is characterized by deletion of the loci for ELN and D7S1870, but not those for D7S2490, D7S2518, or D7S2421. This suggests that a gene responsible for infantile spasms is located in the $2.7-\mathrm{cM}$ interval between loci D7S1870 and D7S675.
\end{abstract}

Key words Williams syndrome $\cdot$ Infantile spasms $\cdot$ Interstitial deletion of $7 \mathrm{q} \cdot$ Elastin gene . DNA polymorphic markers

K. Mizugishi ${ }^{1}(\bowtie) \cdot$ K.Yamanaka $\cdot$ K. Kuwajima

Department of Pediatrics, Ibaraki Handicapped Children's Hospital, Ibaraki, Japan

Tel. +81-298-36-9170; Fax +81-298-36-9040

I. Kondo

Department of Hygiene, Ehime University School of Medicine,

Ehime, Japan

Present address:

${ }^{1}$ Department of Molecular Neurobiology Laboratory, The Institute of Physical and Chemical Research (RIKEN), Tsukuba Life Science

Center, 3-1-1, Kouyadai, Tsukuba, Ibaraki 305-0074, Japan

\section{Introduction}

Williams syndrome (WS) is a well defined developmental disorder that is characterized by distinctive facial features, growth deficiency, mental retardation, a gregarious personality, congenital heart defects (particularly supravalvular aortic stenosis [SVAS] with or without peripheral pulmonary stenosis), and hypercalcemia of early infancy (Williams et al. 1961, Beuren et al. 1962, Morris et al. 1988). Generally, seizures are not associated with WS. Autosomal dominant inheritance has been found in familial WS patients (Sadler et al. 1993, Morris et al. 1993), almost all patients with WS having hemizygosity at the elastin (ELN) locus and submicroscopic deletions of chromosome 7q11.23 (Ewart et al. 1993, Kotzot et al. 1995, Nickerson et al. 1995). LIM-kinase 1 (LIMK1) and the replication factor C subunit 2 (RFC2), have recently been identified in the deleted chromosomal region of the $3^{\prime}$ flanking $E L N$ gene (Frangiskakis et al. 1996, Tassabehji et al. 1996, Peoples et al. 1996, Osborne et al. 1996). Infantile spasms have a wide variety of etiologies and originate from genetically heterogeneous causes. The actual genetic loci, however, have not yet been identified.

We describe a 4-year-old boy with WS and infantile spasms. Interstitial deletion of 7q11.23-q21.1 was detected by cytogenetic methods. To identify one of the genes that may be responsible for infantile spasms, we studied the deleted region of chromosome $7 \mathrm{q}$ in the patient and members of his family, using DNA polymorphic markers.

\section{Methods}

Patient

The patient, a 4-year-old boy, was born at 42 weeks of gestation to a healthy 23-year-old gravida I woman and her healthy, nonconsanguineous 21-year-old husband. The patient's younger, 1-year-old sister was also healthy, and 
there was no family history of developmental delay or mental retardation. The pregnancy was uncomplicated, and delivery was by Cesarean section because of cephalopelvic disproportion. The Apgar score was 9 at $1 \mathrm{~min}$. Weight at birth was $3222 \mathrm{~g}$ (mean); length, $49 \mathrm{~cm}$ (mean); and the occipitofrontal circumference (OFC), $33 \mathrm{~cm}$ (mean). The neonatal period was unremarkable, except that he was kept in an incubator for 2 days because of the aspiration of amniotic fluid.

At 1 month of age, a systolic murmur was found and diagnosed as mild pulmonary stenosis. He underwent surgical repair of a right inguinal hernia at 2 months of age, at which time he suffered a repetitive series of flexor spasms with eye rolling. An immediate electroencephalogram showed hypsarrhythmia intermixed with suppression and burst patterns. Cranial computed tomography disclosed mild cortical atrophy. He was treated with adrenocorticotropic hormone, vitamin B6, valpronate sodium, and nitrazepam, with good results. At 1 year of age, his length was $69.5 \mathrm{~cm}$ (2nd percentile); weight, $6.5 \mathrm{~kg}$ (0.1th percentile), and $\mathrm{OFC}, 44.5 \mathrm{~cm}$ (10th percentile), indicative of the postnatal onset of growth deficiency and poor weight gain. He had poor sucking during infancy.

At age 4 years 10 months, his length was $91.5 \mathrm{~cm}(0.02$ th percentile); weight, $7500 \mathrm{~g}$ (0.02th percentile); and OFC, $46.5 \mathrm{~cm}$ (0.5th percentile). He had a broad forehead, periorbital fullness, large ears, a short nose with a flat bridge, hypertelorism, a long philtrum, micrognathia (Fig. 1) and a small penis. Psychomotor development was severely retarded. He still had difficulty in keeping his head upright, hardly understood directions and could not speak words. His seizures had not been fully controlled. The clini-

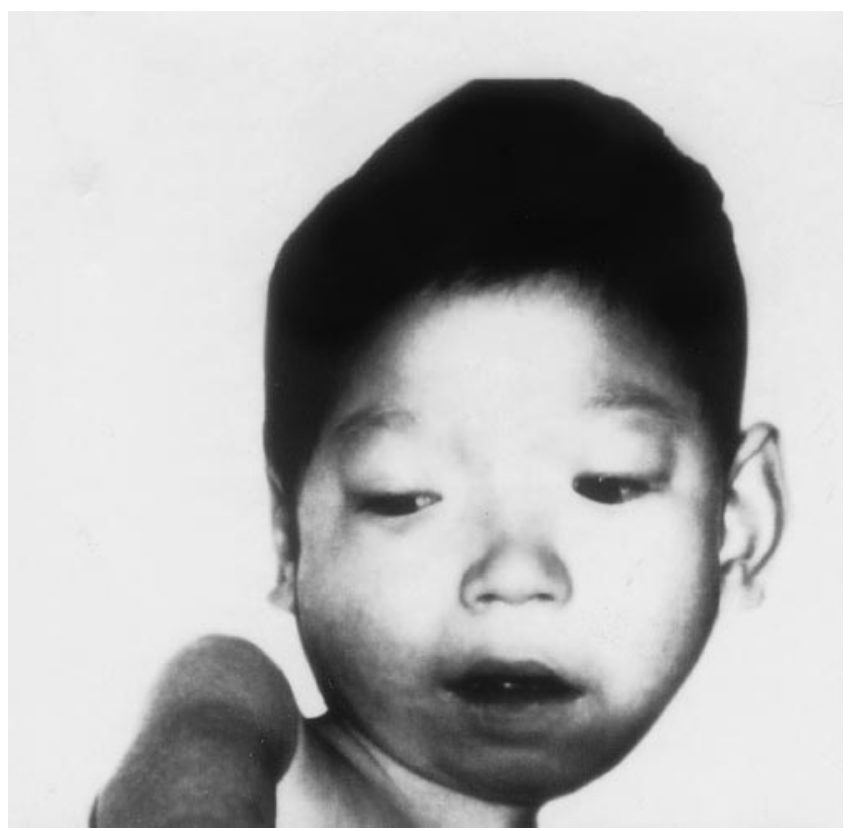

Fig. 1 Patient at age 4 years 10 months. Note the broad forehead, periorbital fullness, large ears, short nose with flat bridge, hypertelorism, long philtrum, and micrognathia (Informed consent to use the photo was obtained.) cal diagnosis was WS with infantile spasms, and he was referred to us for a detailed genetic evaluation.

\section{Cytogenetic analysis}

The patient's karyotype was detected by routine Giemsa banding and high-resolution cytogenetic analysis. Fluorescence in-situ hybridization (FISH) with biotin-labelled cosmids spanning the $5^{\prime}$ (cELN272) and $3^{\prime}$ (cELN11-D) ends of the ELN locus (Oncor, Gaithersburg, MD, USA) was also done.

\section{DNA analysis}

DNAs were obtained from the patient, his parents, and his younger sister. Polymerase chain reaction (PCR) amplification of the ELN gene was done with two primers; 5'CGCTCTAGACAAGGCCTGGGGGAAATTTACATCC-3' and 5'-CGCAAGCTTCTGGAGGCCTGGGAGCCAGTTTG- $3^{\prime}$. The PCR products were digested with the restriction enzyme Mva I (CCAGG) (Toyobo, Tokyo, Japan) and then electrophoresed in a $2 \%$ agarose gel. Polymorphic CA repeats of the DNA markers D7S645, D7S653, D7S1870, D7S2490, D7S2518, D7S2421, and D7S675 (Dib et al. 1996) were amplified from the genomic DNA by the PCR. The PCR products then were electrophoresed in a $3 \%$ agarose gel.

\section{Results}

High-resolution cytogenetic analysis showed the interstitial deletion of chromosome 7q11.23-21.11 (Fig. 2). The patient's parents had normal chromosomes.

FISH results showed that biotin-labelled cosmids bearing the ELN locus produced hybridization signals on one chromosome 7 homologue, but not on the other (data not shown).

The genotypes for the polymorphic ELN gene in the patient and his parents are shown in Fig. 3. The patient has no maternal allele. The haplotypes for the polymorphic markers at ELN and adjacent loci are shown in Fig. 4. The patient is heterozygous for two DNA markers, D7S653 and D7S675, indicative that these DNA markers are outside the area of the deletion of 7q11.23-21.11. Deletion of the maternal ELN and the DNA polymorphic markers D7S1870, D7S2490, D7S2518, and D7S2421, however, was identified in the patient, based on the presence of these genotypes in his family members (Fig. 4).

\section{Discussion}

We detected the interstitial deletion of chromosome 7q11.23-q21.11 in a patient with clinical features of WS and infantile spasms. The diagnosis of WS was confirmed by FISH, which showed hemizygosity at the ELN locus. 


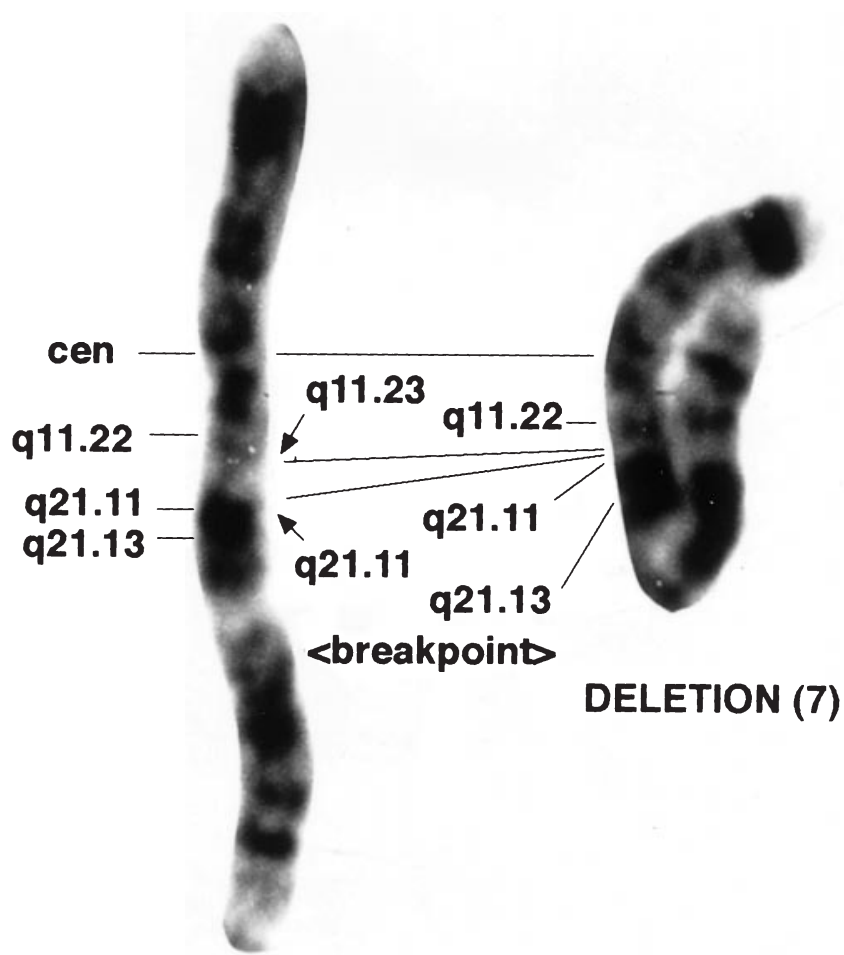

\section{CHROMOSOME 7}

Fig. 2 High-resolution G-banding karyotypes of the patient's chromosome 7, showing the interstitial deletion of 7q11.23-q21.11. Arrows indicate the breakpoints

Fig. 4 Haplotypes for polymorphic markers at the $E L N$ gene and adjacent loci. There is a deletion of maternal loci from ELN to D7S2421 in the patient. $A, B, C, 2$ and 3 indicate the genotypes. Black square indicates the patient. Black and checked columns indicate paternal chromosomes while striped and white columns indicate maternal chromosomes

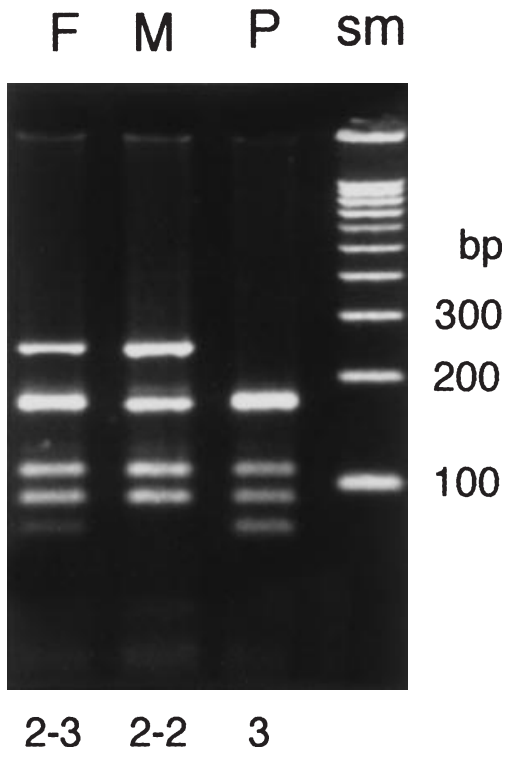

Fig. 3 Genotypes of the polymorphic ELN gene marker in the patient and his parents. Polymerase chain reaction (PCR) products digested with the restriction enzyme Mva I give three polymorphic alleles, types 1,2 , and 3 . Type 1 has fragments of $18,11,17,89,111,167$, and $262 \mathrm{bp}$; type 2 , fragments of $8,11,17,18,89,111,167$, and $244 \mathrm{bp}$; and type 3 has an additional DNA substitution compared to type 2, which creates a new restriction site, resulting in fragments of $8,11,17,18,60-70,89$, 111,167 , and $170-180 \mathrm{bp}$. The genotypes show the failure of the patient to inherit the maternal allele. Numerals 2 and 3 indicate the genotypes. $F$, Father; $M$, mother; $P$, patient; $S M$, DNA size marker
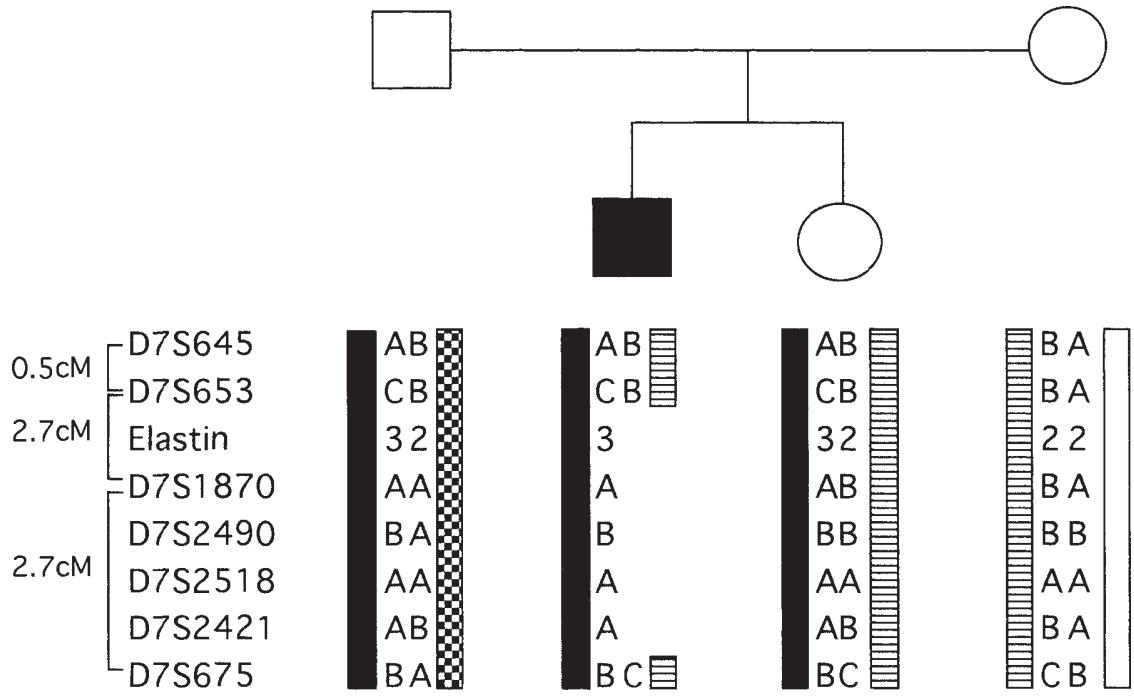

The ELN deletion was de novo and maternally derived.

The genetic order of the loci, 7cen-D7S645-D7S672D7S653-D7S1483-D7S1816-D7S489B-D7S2476-D7S613ELN-D7S2472-D7S1870-D7S2490-D7S2518-D7S2421-D7S675 -D7S669-7qter, has been reported (Dib et al. 1996; PérezJurado et al. 1996). In almost all patients with WS, loci from D7S489B through D7S1870 are deleted, but the location of the distal breakpoint is heterogeneous (Pérez-Jurado et al.
1996). The genetic distance between loci D7S489B and D7S1870 is estimated to be 2cM, and to consist of two mega base pairs (2Mbp) (Pérez-Jurado et al. 1996). The chromosomal deletion detected microscopically is suggested to be more than $2 \mathrm{Mbp}$, indicating that it is difficult to detect the deletion in patients with WS by routine cytogenetic analysis. Clinically, a history of seizures is not typical of WS. Our patient, however, had clinical features of WS and infantile spasms, and the microscopically detectable chromosomal 
deletion of 7q11.23-q21.11. DNA analysis confirmed the deletion of ELN and the DNA markers D7S1870, D7S2490, D7S2518, and D7S2421, but not of the marker D7S675. We therefore speculate that a gene responsible for infantile spasms is located in the deleted region between the D7S1870 and D7S675 markers.

Interstitial deletion of 7q11.2-q22 has been reported in 16 patients, and at least 6 had associated abnormal EEGs, seizures, or both (Zackowski et al. 1990). Crawfurd et al. (1979) reported a patient with a karyotype of 46,XY,del (7) (q11q21), who showed developmental delay, hypotonia, and infantile spasms. Young et al. (1984) reported a 10year-old girl who suffered recurrent pneumonia, growth deficiency, severe psychomotor delay, and seizures, with an EEG showing hypsarrhythmia. Her karyotype was 46,XX,del (7) (q11.21q21.11). Recently, Kahler et al. (1995) reported a patient who had the features of WS and infantile spasms. In addition, he had severe mental retardation and absence of speech, which are not typical of WS. His karyotype showed 46,XY,del (7) (q11.23q21.11), as did that of our patient. These cases support the possibility that a gene for infantile spasms exists in the commonly deleted 7q11q21 region, in particular, 7q11.23-q21.11.

Infantile spasms have a wide variety of causes. Some other chromosomal aberrations are reported to be associated with infantile spasms, hypsarrhythmia, or both; chromosome $2 \mathrm{p}$ partial trisomy, balanced translocations, $\mathrm{t}$ (6;14), t (5;11), ring chromosome 14, chromosome 15 partial tetrasomy, and chromosome 21 trisomy (Mitsudo et al. 1982; Hattori et al. 1985; Jacob 1974; Schmidt et al. 1981; Kobayashi et al. 1994; Tatsuno et al. 1984). The genetic causes of infantile spasms, therefore, are heterogeneous. Our findings suggest that one gene responsible for infantile spasms is present in 7q11.23-q21.11, in particular, in the 2.7$\mathrm{cM}$ interval between D7S1870 and D7S675. More genetic evidence, however, is required to confirm this possibility.

\section{References}

Beuren AJ, Apitz J, Harmjanz D (1962) Supravalvular aortic stenosis in association with mental retardation and a certain facial appearence. Circulation 26: 1235-1240

Crawfurd M d'A, Kessel I, Liberman M, Mckeown JA, Mandalia PY, Ridler MAC (1979) Partial monosomy 7 with interstitial deletions in two infants with differing congenital abnormalities. J Med Genet 16: $453-460$

Dib C, Fauré S, Fizames C, Samson D, Drouot N, Vignal A, Millasseau P, Marc S, Hazan J, Seboun E, Lathrop M, Gyapay G, Morissette J, Weissenbach J (1996) A comprehensive genetic map of the human genome based on 5264 microsatellites. Nature 380: 152-154

Ewart AK, Morris CA, Atkinson D, Jin W, Sternes K, Spallone P, Stock AD, Leppert M, Keating MT (1993) Hemizygosity at the elastin locus in a developmental disorder, Williams syndrome. Nature Genet 5: 11-16

Frangiskakis JM, Ewart AK, Morris CA, Mervis CB, Bertrand J, Robinson BF, Klein BP, Ensing GJ, Everett LA, Green ED, Pröschel C, Gutowski NJ, Noble M, Atkinson DL, Odelberg SJ, Keating MT (1996) LIM-kinase 1 hemizygosity implicated in impaired visuospatial constructive cognition. Cell 86: 59-69

Hattori H, Hayashi K, Okuno T, Temma S, Fujii T, Ochi J, Mikawa H (1985) De novo reciprocal translocation $\mathrm{t}(6 ; 14)(\mathrm{q} 27 ; \mathrm{q} 13.3)$ in a child with infantile spasms. Epilepsia 26: 310-313

Jacob PA (1974) Correlation between euploid structural chromosome rearrangements and mental subnormality in humans. Nature 249: 164-165

Kahler SG, Adhvaryu SG, Helali N, Qumsiyeh MB (1995) Microscopically visible deletion of chromosome 7 in a child with features of Williams syndrome (abstract). Am J Hum Genet 57: 117

Kobayashi A, Ito M, Okada M, Yoshioka K (1994) A case of 15p tetrasomy associated with infantile spasms. No To Hattatsu 26: 74-77

Kotzot D, Bernasconi F, Brecevic L, Robinson WP, Kiss P, Kosztolanyi G, Lurie IW, Superti-Furga A, Schinzel A (1995) Phenotype of the Williams-Beuren syndrome associated with hemizygosity at the elastin locus. Eur J Pediatr 154: 477-482

Mitsudo K, Tanaka M, Hayashi K, Ukita M, Kajitani T, Kitano H (1982) A case of partial $2 p$ trisomy with thyroxine binding globulin deficiency. Ann Paediatr Jpn 28: 154

Morris CA, Demsey SA, Leonard CO, Dilts C, Blackburn BL (1988) Natural history of Williams syndrome: Physical characteristics. J Pediatr 113: 318-326

Morris CA, Thomas IT, Greenberg F (1993) Williams syndrome: Autosomal dominant inheritance. Am J Med Genet 47: 478-481

Nickerson F, Greenberg F, Keating MT, McCaskill C, Shaffer LG (1995) Deletions of the elastin gene at 7q11.23 occur in $\sim 90 \%$ of patients with Williams syndrome. Am J Hum Genet 56: 1156-1161

Osborne LR, Martindale D, Scherer SW, Shi XM, Huizenga J, Heng HHQ, Costa T, Pober B, Lew L, Brinkman J, Rommens J, Koop B, Tsui LC (1996) Identification of genes from a 500-kb region at $7 \mathrm{q} 11.23$ that is commonly deleted in Williams syndrome patients. Genomics 36: 328-336

Peoples R, Pérez-Jurado LA, Wang Y-K, Kaplan P, Francke U (1996) The gene for replication factor $\mathrm{C}$ subunit 2 (RFC2) is within the 7q11.23 Williams syndrome deletion. Am J Hum Genet 58: 13701373

Pérez-Jurado LA, Peoples R, Kaplan P, Hamel BCJ, Francke U (1996) Molecular definition of the chromosome 7 deletion in Williams syndrome and parent-of-origin effects on growth. Am J Hum Genet 59: 781-792

Sadler LS, Robinson LK, Verdaasdonk KR, Gingell R (1993) The Williams syndrome: Evidence for possible autosomal dominant inheritance. Am J Med Genet 47: 468-470

Schmidt R, Eviatar L, Nitowsky HM, Wong M, Miranda S (1981) Ring chromosome 14: A distinct clinical entity. J Med Genet 18: 304-307.

Tassabehji M, Metcalfe K, Fergusson WD, Carette MJA, Dore JK, Donnai D, Read AP (1996) LIM-kinase deleted in Williams syndrome. Nature Genet 13: 272-273

Tatsuno M, Hayashi M, Iwamoto H, Suzuki Y, Kuroki Y (1984) Epilepsy in childhood Down syndrome. Brain Dev 6: 37-44

Williams JCP, Barrat-Boyers BG, Lowe JB (1961) Supravalvular aortic stenosis. Circulation 24: 1311-1318

Young RS, Weaver DD, Kubolich MK, Heerema NA, Palmer CG, Kawira EL, Bender HA (1984) Terminal and interstitial deletions of the long arm of chromosome 7: A review with five new cases. Am J Med Genet 17: 437-450

Zackowski JL, Raffel LJ, Blank CA, Schwartz S (1990) Proximal interstitial deletion of 7q: A case report and review of the literature. Am J Med Genet 36: 328-332 